
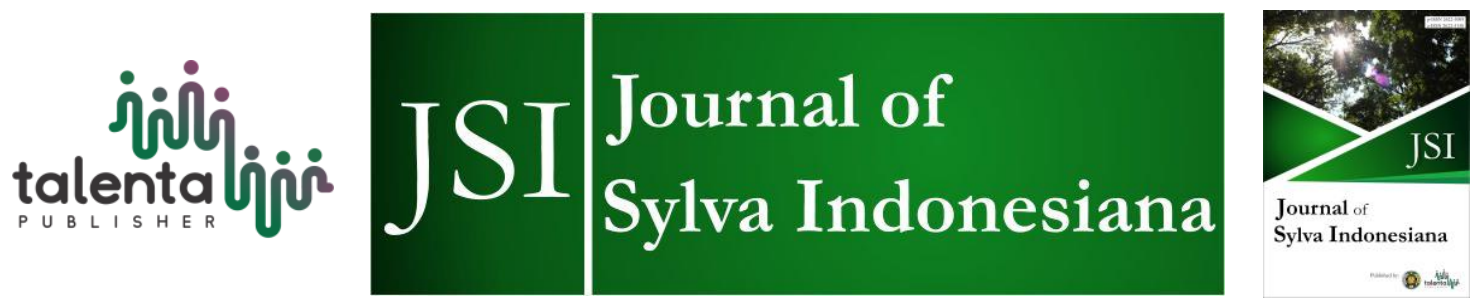

\title{
Application of Point Sampling Method in Estimation of Stand Basal Area in Community Forest
}

\author{
Budi Mulyana', Rohman ${ }^{2}$, and Ris Hadi Purwanto ${ }^{3}$ \\ ${ }^{1,2,3}$ Faculty of Forestry, Gadjah Mada University, Yogyakarta, Indonesia
}

\begin{abstract}
Estimation of the potency of community forest is usually done with the census approach for each forest. Sampling methods to estimate the potency of community forest still rare. The size of community forest is relatively small, scatter, and less irregular shape, therefore the estimation of community forest potency using sampling plot is difficult to apply. The approach of sampling without a plot (plotless/ point sampling) was cheaper and faster compare to the method of sample plots and direct measurement (census) in predicting basal area. The objective of this research is determining the difference in the average value of basal area using direct measurement of stand (census) and point sampling methods. The research was carried out for 4 months in 30 community forests at Kemuning Village, Gunungkidul District. Materials used to estimate basal area with point sampling method were Spiegel Relascope and Bitterlich Stick with the value of Basal Area Factor 1. Parameters measured were diameter at breast high (dbh) for census method and the number of trees were categorized in or border for point sampling method. The result was analyzed statistically using unpaired $t$-student. The result showed that the average of basal area of tree in community forest with point sampling method were no significantly different from the average of basal area with census method $(\alpha=1 \%)$. Therefore, the point sampling method can be considered as a tool in inventory at community forest.
\end{abstract}

Keyword: Basal Area, Community Forest, Forest Inventory, Point Sampling, Plotless.

Received 30 January 2018 | Revised 22 April 2018 | Accepted 30 July 2018

\section{Introduction}

Community forests have an important role to fulfill the needs of wood and maintaining the quality of the environment. The area of community forest in Java Island for the past 18 years (1990-2008) has increased by $2 \%$ per year [1]. Timber supplies from community forests in Central Java Province and Special Region of Yogyakarta in the period of 2003-2007 reached more than 1 million $\mathrm{m}^{3}$ or more than $50 \%$ of total timber supply in the province [2]. The development of community forests is supported by a good public perception of the economic and ecological benefits of community forests [3] and local government [4].

\footnotetext{
*Corresponding author at: Gadjah Mada University, Yogyakarta 55281, Indonesia E-mail address: budimulyana@ugm.ac.id
} 
Community forest is generally planted with more than one species. The tradition, farmer's experiences and previous successes stories are determining factors of species variation in the development of community forest [3]. Community forests in Java generally have several characteristics, namely: 1) pure timber trees, 2) a mixture of timber trees with fruits, 3) a mixture of timber trees, fruits, spice and herb plants [5]. Similar characteristic also occur in South Kalimantan, where community forests use monoculture and multicultural patterns according to the needs of landowners [4]. Community forest in Riau continuously planted with one species causing the decrease of yield productivity, low genetic diversity, and vulnerable to pest attack [6]. On community forests with small area, it is recommended to mix forest plants, fruits, spice and herb plants, and fodder [7].

The current community forest management in general is still limited to planting and harvesting. The maintenance and inventory of stand potential needs further studies. Small-scale timber concessions have different characteristics than those in general industrial plantations, thus requiring different inventory approaches [8]. The challenge of small scale forests inventory are small areas, overgrown with few plants and the location is scattered [8].

Data and information in forest inventory activities can be obtained by census or sampling methods. Sampling is more commonly used because it's cheaper, faster, and the precision can be determined [9]. Forest inventory sampling can be conducted using fixed plot sampling or plotless sampling methods $[9,10]$.

Due to the forest managers' lack of knowledge, plotless sampling method has rarely been used in forest inventory in Indonesia [9]. Plotless sampling method was introduce by Walter Bitterlich in the 1940s, popularly known as the Bitterlich method or point sampling. This method is applied in estimating the basal area without measuring the tree diameter or making plots [11].

The point sampling method has several advantages in basal area estimation. The cost is low and it can be done quickly, flexibly, and accurately $[11,12]$. Variables that are easily obtained in estimating stand biomass are basal area and age [13]. The Bitterlich method is more accurate and efficient in estimating basal area and volume of pine stands [14].

The point sampling method is applied in even-aged forest inventories [15, 16], but has also been applied in mixed stands [17, 18], in protected forests and community forests [19]. Previous study compared the n-tree sampling method with point sampling and plot sampling methods in three forest types (hardwood stands, red pine stands, and mixed hardwood stands) [17]. Franklin et al. [18] developed a model of canopy cover type in mixed forest (wide and needle leaf species) using point sampling, fixed plot, and satellite image data. Timilsina et al. [19] combined point sampling method and transect sampling method to find out the structure and composition of forest and community forest. 
The basal area of stands in the community forest can be estimated more simply using point sampling method. It is plotless and simple. The estimation was obtained by counting the sample trees, those which included in 'in' and 'border' tree categories, during the observation.

The community forests have diverse characters and are composed by more than one species with various ages. Estimating the potential of community forests by the census method produces actual results, but requires considerable cost and manpower. The point sampling method can save cost and manpower but the result of its assessment needs further study. This study aims to compare the mean value of the basal area of stand in the community forest using the census method and the point sampling method.

\section{Materials and Methods}

The research was conducted in community forest of Dusun Kemuning, Patuk Sub-district, Gunungkidul Regency from June to September 2016. We used 30 land units with various sizes as sample plots. The tools used in this research ware tape meter, Spiegel Relascope, and Bitterlich stick. The measurement of tree diameter at breast height (dbh) for the census method was carried out in all 30 lands units. The point sampling was done using Spiegel Relascope and Bitterlich stick, also in all 30 lands units. There were 360 observations in total.

The average area of community forest in the study was $2,257 \mathrm{~m}^{2}$. The smallest area was $528 \mathrm{~m}^{2}$ and the largest was $7,200 \mathrm{~m}^{2}$. The selected plots for research were obtained after the local government communicated with the lands owner to ask their permissions. Communications between landowners and government authorities were required in small-scale forest inventories in order to obtain adequate data and information with regard to ownership limits, plant age, and management [8].

We collected tree circumference values and used census method for each area. The circumference values were then converted to the diameter of the tree to obtain the basal area value of the stand. The total basal area in each field is obtained by summing the basal area of all stands in the field.

Basal area value in point sampling methods obtained using Spiegel Relascope and Bitterlich stick. Basal Area Factor (BAF) used in this study was BAF 1. The observation of tree position using point sampling method was conducted in three points at the community forest area (Figure 1). Lindsey et al. [20] studied three observation points from the midpoint of the plot. To estimate the basal area value, sampling points should be spread evenly within the area [12].

The point sampling observations conduct by two observers. The observation for basal area value estimation of stand should be done more than once [20]. The average basal area value of each 
community forest was obtained by adding basal area values from each observation point then divided by the number of observations.

Statistical analysis was performed using paired t-student test. The basal area value obtained by the measurement of census method was compared to the basal area value of point sampling obtained by using the Bitterlich stick and Spiegel Relascope.

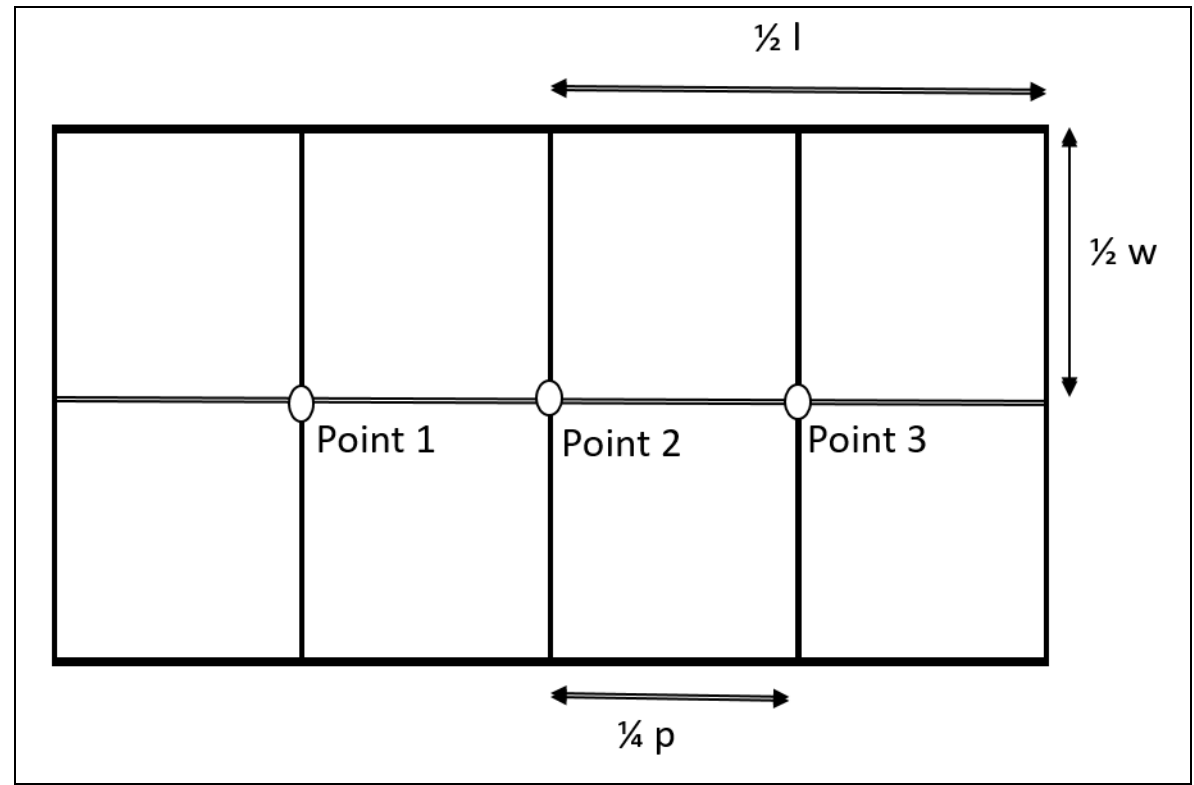

Description

I : length of the community forest area

W : width of the community forest area

Figure 1 The observation points for point sampling method

\section{Result and Discussion}

\subsection{The basal area at the community forest}

The community forest in Dusun Kemuning, Patuk Sub-district, Gunungkidul Regency were generally planted with teak and had not been treated intensively. Most of area abandoned by their owners after harvesting. There were no fixed pattern or plan for planting. The regeneration was a natural-growing seedlings and coppice, thereby increasing the plant density. Untreated and unmaintained community forests were caused by farmers' limited capital [21].

The community had not been managing their community forest intensively. The necessary of data and information of forest area for community forest planning was still unrecognized. The most accessible data and information obtained from the community forest was the circumference of trees, which was measured directly at breast height (dbh) using a measuring tape. The value obtained was the true value, not the estimated value. Commonly, estimation 
value in forest inventory was tree height which measured geometrically because it was difficult to conduct direct measurement from the soil surface to the canopy.

The basal area was recorded in $\mathrm{m} 2 / \mathrm{ha}$. The measurement of tree circumference in the census method was performed on all trees. The circumference value of each tree was then used to calculate the basal area value. The total basal area value was obtained by summing up all the basal area values of trees located on the community forest area.

The basal area value in point sampling method was obtained by calculating the 'in' category trees, border category trees, and out category trees. The BAF used in this point sampling method had a value of 1 , so the 'in' category trees were given a value of 1 , the 'border' category trees were given a value of 0.5 , and the 'out' category trees were given a value of 0 . The basal area value using point sampling method was obtained by summing basal area values taken at three observation points. The irregular size pattern in the community forest area affected different levels of plant density in a single field. Therefore, more observations are required to obtain estimated basal area value for every community forest area. The average basal area value in the community forest in the research site was about $11-12 \mathrm{~m}^{2} /$ ha, as shown in Table 1 .

Table 1 The basal area in 30 communities forest area at Dusun Kemuning

\begin{tabular}{lccccc}
\hline \multirow{1}{*}{ Method } & Lowest & Highest & Mean & $\begin{array}{c}\text { Standard } \\
\text { Deviation }\end{array}$ & $\begin{array}{c}\text { Precision } \\
(\%)\end{array}$ \\
\cline { 2 - 5 } & 2.48 & 29.10 & 11.51 & - & \\
\hline $\begin{array}{l}\text { Census } \\
\text { Point sampling using }\end{array}$ & 1.00 & 29.67 & 11.03 & 6.27 & 56.91 \\
$\begin{array}{l}\text { Bitterlich stick } \\
\begin{array}{l}\text { Point sampling using Spiegel } \\
\text { Relascope }\end{array}\end{array}$ & 1.33 & 32.08 & 12.24 & 6.67 & 54.48 \\
\hline
\end{tabular}

The basal area values in community forests with multicultural pattern were $10.62 \mathrm{~m}^{2} /$ ha (Sukabumi) and $17.94 \mathrm{~m}^{2} /$ ha (Pandeglang) [21]. The community forest in Dusun Kemuning has similar characteristics to their sites: multicultural pattern and average diameter (dbh) below 20 $\mathrm{cm}$.

The mean value of basal area using census method and point sampling method were applied to paired t-student test showed no significant difference at 99\% confidence level. Both Spiegel Relascope and Bitterlich stick were capable to estimate the basal area and the results was not significantly different from the basal area value of the census method. The point sampling method is more accurate than other sampling methods in basal area value estimation [14].

The mean value of basal area by point sampling method from three observation points was not significantly different with basal area value by census method. Compared to census method, the 
basal area values of point sampling method differentiated into underestimate (below), approximate (almost similar), and overestimate (higher) groups.

The basal area value estimated using point sampling method was not as accurate as basal area value obtained by census method. The impact of the basal area value difference estimated using point sampling method was the high diversity. Furthermore, sampling error (SE) for point sampling method was also being calculated. The SE value of each community forest area at $\alpha=$ 0.05 for each community forest area was vary. The smallest and highest SE value was $23.32 \%$ and $135.83 \%$, respectively.

The point sampling method resulted in a sampling error value was above $20 \%$ allegedly due to the following factors:

1. The selection of basal area factor (BAF) on point sampling. Low BAF will increase not only the sample trees but also the error [9]. The BAF value 1 in this study was selected with consideration of the plant age in community forest was still relatively young with dominated diameter below $20 \mathrm{~cm}$ (as shown histogram in Figure 2). BAF 1 was selected for small standing / young stands, BAF 4 for medium-sized stands, and BAF 9 for large-sized stands [9].

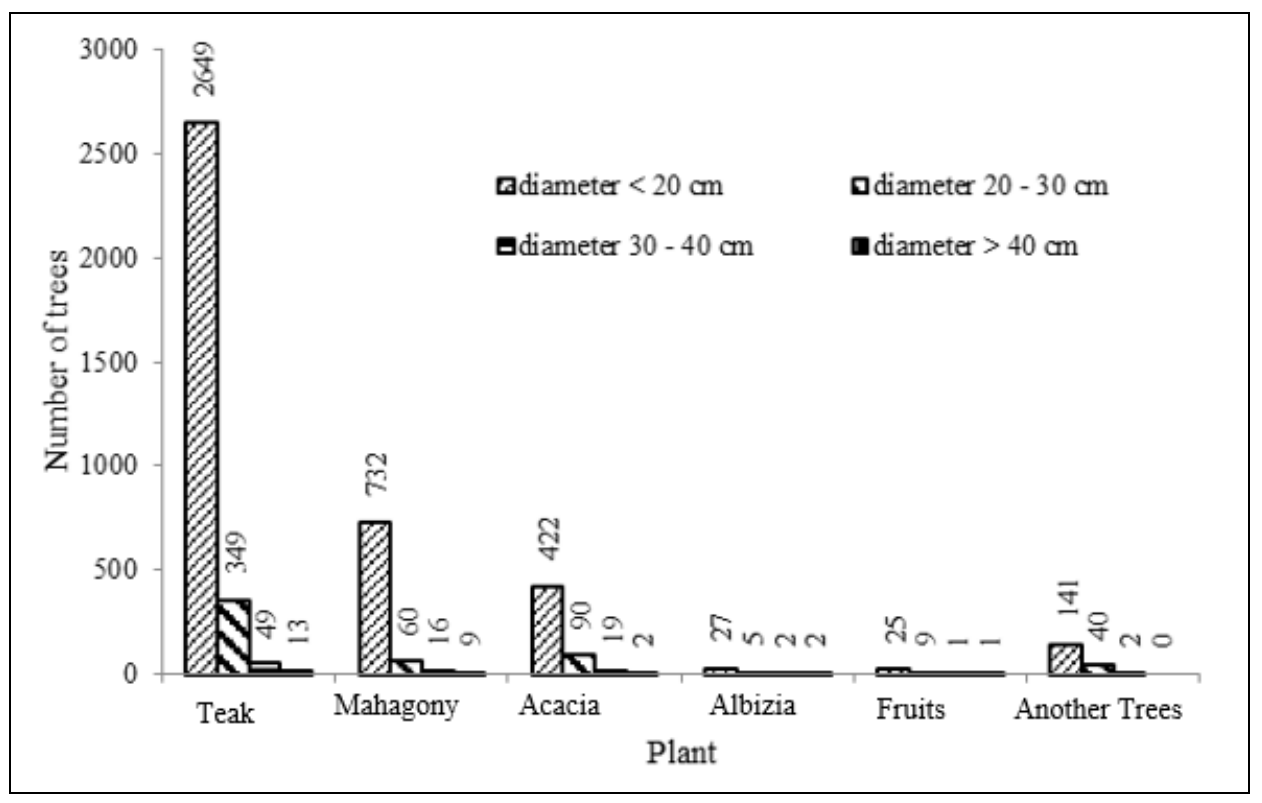

Figure 2 Distribution of tree diameter in community forest

2. Different conditions of community forests (density, species composition, agroforestry systems) causing the distribution of trees became uneven stand. Cultivation in community forests generally has no pattern/irregular $[4,5]$. We also found rarely overgrown (low BAF value) and dense (high BAF value) observation points. 
The basal area has a strong and positive relationship with the number of trees $(\mathrm{R} 2=0.7743)$. $77.43 \%$ of the diversity of the basal area values was caused by the tree numbers value and the rest is influenced by other factors. The addition of the number of trees in a field will increase the value of the basal area of the stand (Figure 3).

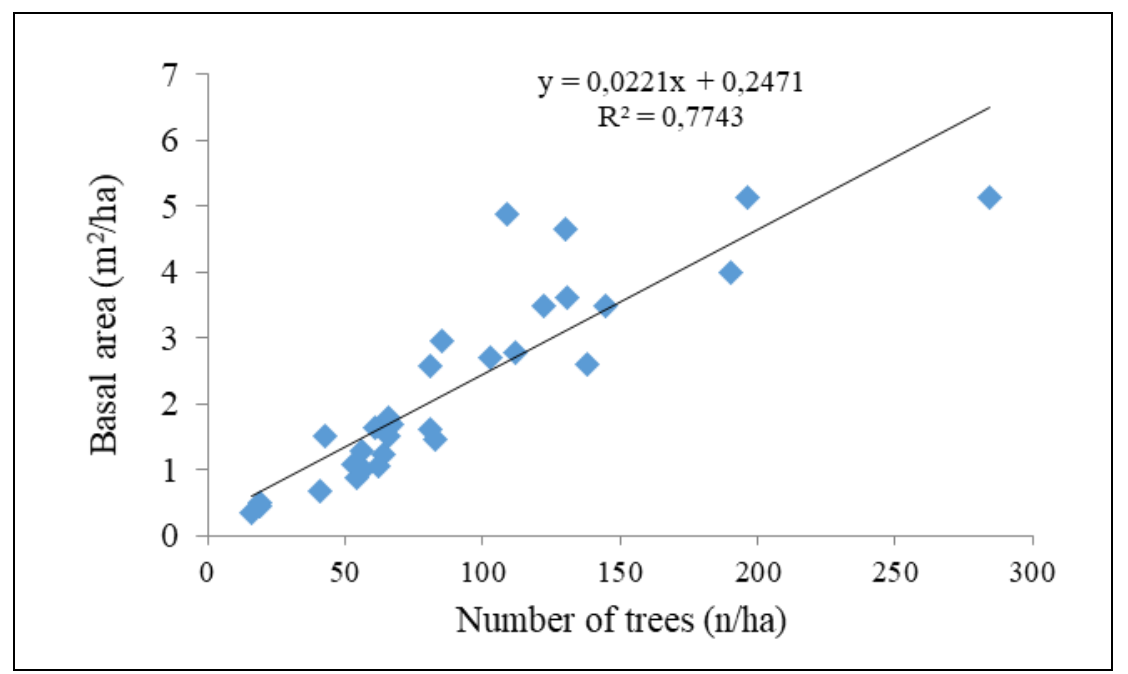

Figure 3 Relation between the basal area and the number of trees in the community forest

The correlation coefficient value that reaches above $75 \%$ showed that the size of trees in the forest was relatively homogeneous. Thus, the addition of the number of trees will be followed by the addition of basal area value. The diameter of the homogeneous trees at site was below 20 $\mathrm{cm}$.

The basal area does not significantly related to the forest area $(\mathrm{R} 2=0.0321)$. Large community forest area is not always densely planted. Thus, the addition of community forest area is not always followed by the addition of basal area value. In this study, highest density area was located at Suyono's plot, which had 62 trees on $528 \mathrm{~m}^{2}$ area. The lowest density was located at Marsono's plot, which had 66 trees on 7,200 $\mathrm{m}^{2}$ area. The density of trees in community forest was influenced by the area size and applied farming pattern [22].

Bitterlich Sticks and Spiegel Relascope are capable to estimate the basal area in a community forest. Considering the cost and easy to operate in the field, Bitterlich stick is more recommended. Compared to Spiegel Relascope, it has following advantages:

1. The result was not significantly different.

2. By following the geometry theory that has been set in point sampling method, Bitterlich sticks can be made by hand.

3. Lower cost. 


\subsection{The diameter distribution for each plant species in the community forest}

The community forests in this study were dominated by teak (Table 2). The forest composed by multi-species plants. In several locations, the farmers combined trees and agricultural crops. The community forest in Dusun Kemuning had an average land area of 2,257 $\mathrm{m}^{2}$ and an average tree density of 504 trees/ ha. It was almost in line with the definition of community forest based on Minister of Forestry Decree no. 49/Kpts-II/1997on Funding and Community Forest Business, which stated that the minimum number of trees in the community forest is 500 trees/ha, the minimum area of 0.25 ha, and canopy cover at least $50 \%$. The community forest area in Dusun Kemuning was in the yard, moor, or forest. The size of the area, the type of plants and the size of the tree were vary.

Table 2 Types of tree in the community forest of Kemuning Village

\begin{tabular}{|c|c|c|c|}
\hline No & Types & Number & Percentage $(\%)$ \\
\hline 1 & Acacia & 466 & 13.67 \\
\hline 2 & Teak & 2,098 & 61.52 \\
\hline 3 & Mahogany & 602 & 17.65 \\
\hline 4 & Albizia & 34 & 1.00 \\
\hline 5 & Fruits & 34 & 1.00 \\
\hline 6 & Another trees & 176 & 5.16 \\
\hline & Total & 3,410 & 100.00 \\
\hline
\end{tabular}

The community forest in Kemuning was dominated by teak species with diameter below $20 \mathrm{~cm}$. The community forest with mixed garden pattern also showed the average diameter of staple crops in a community forest of $18 \mathrm{~cm}$ [21]. Teak is a staple crop chosen by the community to be developed in the community forest with the consideration of higher selling price and easy to market.

Other than teak, the community forest in Dusun Kemuning was also planted with albizia, mahogany, fruit trees (mango, guava, jackfruit, breadfruit), and other types (melinjo, coconut, Tamarindusjavanica). This is in accordance with the previous research $[5,21,23,24]$, that communities forests in Java Island have polyculture characteristics with more than 2 plants are cultivated.

\section{Conclusion}

The estimation of the mean basal area in the community forest using point sampling method was not significantly different from the average value of the basal area using census method. The point sampling method can be considered for use in community forest inventory by increasing the number of samples, using a more optimal BAF, and distribution of sample points. 


\section{Acknowledgement}

We would like to thank the Faculty of Forestry Gadjah Mada University that has funded the research, and to all parties who have helped us in the process of the research. We would also like to thank the anonymous reviewers and colleagues at Faculty of Forestry Gadjah Mada University who has provided constructive and valuable advices in the process of article writing.

\section{REFERENCES}

[1] BPKH XI, and MFP, Strategi Pengembangan Pengelolaan dan Arahan Kebijakan Hutan Rakyat di Pulau Jawa, Yogyakarta: Balai Pemantapan Kawasan Hutan (BPKH) XI Jawa Madura colaboration with Multistakeholder Forestry Programme (MFP), 2009.

[2] H. Dwiprabowo, "Kajian pasokan kayu perkakas di Propinsi Jawa Tengah dan DIY," Jurnal Penelitian Sosial dan Ekonomi Kehutanan, vol. 5, no. 3, pp. 203-215, 2008.

[3] B. Achmad, H. Simon, D. Diniyati, and T. S. Widyaningsih, "Persepsi petani terhadap pengelolaan dan fungsi hutan rakyat di Kabupaten Ciamis," Jurnal Bumi Lestari, vol. 2, no. 1, pp. 123-136, 2012.

[4] G. S. Noor, "Perkembangan hutan rakyat di Provinsi Kalimantan Selatan," Jurnal Bina Praja, vol. 6, no. 4, pp. 307-314, 2014.

[5] N. A. Jariyah, and N. Wahyuningrum, "Karakteristik hutan rakyat di Jawa," Jurnal Penelitian Sosial dan Ekonomi Kehutanan, vol. 5, no. 1, pp. 43-56, 2008.

[6] A. Sudomo, P. Permadi, and E. Rachman, "Kajian kontrol silvikultur hutan tanaman terhadap kualitas kayu pulp,” Info Teknis, vol. 5, no. 2, pp. 1-10, 2010.

[7] S. Irawanti, A. P. Suka, and S. Ekawati, "Peranan kayu dan hasil bukan kayu dari hutan rakyat pada pemilikan lahan sempit: kasus Kabupaten Pati," Jurnal Penelitian Sosial dan Ekonomi Kehutanan, vol. 9, no. 3, pp. 113-125, 2012.

[8] J. L. Herbohn, J. Vanclay, H. Nguyen, H. D. Le, J. Baynes, S. R. Harrison, E. Cedamon, C. Smith, J. Firn, N. O. Gregorio, E. Mangaoang, and E. Lamarre, "Inventory procedures for smallholder and community woodlots in the Philippines: method, initial findings, and insight," Small-scale Forestry, vol. 13, no. 1, pp. 79-100, 2014.

[9] H. Simon, Metode Inventore Hutan, Yogyakarta: Pustaka Pelajar, 2007.

[10] F. Loetsch, and K. E. Haller, Forest inventory. Volume I. Statistics of forest inventory and information from aerial photographs, Munich: BLV Verlagsgesellschaft, 1964.

[11] H. J. Hovind, and C. E. Rieck, Basal Area and Point Sampling Interpretation and Application, Wisconsin USA: Wisconsin Conservation Department: Technical Bulletin No.23, 1961.

[12] P. D. Bropleh, "Applicability of point sampling to the forests of Liberia," Thesis, Oregon State University, 1967.

[13] T. Tiryana, S. Tatsuhara, and N. Shiraishi, "Empirical Models for Estimating the Stand Biomass of Teak Plantations in Java, Indonesia," Journal of Forest Planning, vol. 16, pp. 177-188, 2011.

[14] J. P. Druszcz, S. do Amaral Machado, N. Y. Nakajima, N. C. Rosot, and R. T. Hosokawa, "Efficiency of the bitterlich point sampling and the method of fixed area sampling with structural variations in Pinus taeda plantations," Floresta, vol. 45, no. 3, pp. 523-534, 2015.

[15] R. E. Shanks, "Plotless Sampling Trials in Appalachian Forest Types," Ecology, vol. 35, no. 2, pp. 237-244, 1954. 
[16] P. Becker, and T. Nichols, "Effects of basal area factor and plos size on precision and accuracy of forest inventory estimates," Northern Journal of Applied Forestry, vol. 28, no. 3, pp. 152-156, 2011.

[17] V. Lessard, D. D. Reed, and N. Monkevich, "Comparing N-Tree Distance Sampling with Point and Plot Sampling in Northern Michigan Forest Types," Northern Journal of Applied Forestry, vol. 11, no. 1, pp. 12-16, 1994.

[18] S. E. Franklin, M. B. Lavigne, M. J. Deuling, M. A. Wulder, and E. R. Hunt, "Landsat TM derived forest covertypes for modelling net primary production," Canadian Journal of Remote Sensing, vol. 23, no. 3, pp. 243-251, 1997.

[19] N. Timilsina, M. S. Ross, and J. T. Heinen, “A community analysis of sal (Shorea robusta) forests in the western Terai of Nepal," Forest Ecology and Management, vol. 241, no. 1, pp. 223-234, 2007. 